\title{
Common Agricultural Policy Implications in the Evolution of Romanian Agriculture Geography
}

\author{
Liliana Mihaela Moga ${ }^{1,2}$ and Valentin Marian Antohi ${ }^{1}$ \\ ${ }^{1}$ Dunarea de Jos University of Galati, Galati, Romania \\ ${ }^{2}$ The Bucharest University of Economic Studies, Bucharest, Romania
}

Received 29 January 2012; Accepted 16 September 2012; Published 27 February 2013

Academic Editor: Miltiade Stanciu

\begin{abstract}
This paper is focused on patterns and changes in regional specialization and geographic concentration of agriculture as economic activity. The study is focused mainly on the evolution of Agriculture, as economic activity. It is studied the evolution of regional specialization and geographic concentration in Romania at NUTS2 level, by underlining the impact of the implementation of the Common Agricultural Policy and the integration of the Romanian agriculture in the European Market. The statistical indicator used within the empirical study is Krugman Index. The results of the study show that the transformations that occurred at the level of the Romanian economy in the process of pre-accession and post accession to the European Union led to minor changes in specialization of agriculture.
\end{abstract}

Keywords: Agriculture, regional specialization, geographic concentration, development regions, Common Agricultural Policy.

\section{Introduction}

The political economy of the Common Agricultural Policy has been discussed widely with a view to understanding the large European Union budget expenditures on the Common Agricultural Policy and the distortions within the European Union and on world markets (Council of the European Union, 1999; Council of the European Union, 2006). The Common Agricultural Policy is organized on two pillars. First is the sectoral pillar which manages the measures of market and income policy, while the second pillar, termed territorial pillar, manages the rural development policy (Zahiu, Dachin and Manole, 2006). The decision making process on the Common Agricultural Policy is an institutionally complex procedure, in which the member state governments, the European Commission, and the Council of the European Union all play an important role (Swinnen, 2008).

The 2007 enlargement of the European Union to 27 member states has caused changes in the structure and guidance of budgetary expenditures for supporting the reform measures, the new structure of farms and reducing of gaps in the development of rural areas. At regional

Copyright (C) 2013 Liliana Mihaela Moga and Valentin Marian Antohi. This is an open access article distributed under the Creative Commons Attribution License unported 3.0, which permits unrestricted use, distribution, and reproduction in any medium, provided that original work is properly cited. Contact author: Liliana Mihaela Moga E-mail: liliana.moga@gmail.com 
level, Romania is distinguished by differences given by geographical and environmental characteristics, demographic situation as well as socialeconomic features. Because of the restructuring of the land property almost the entire agricultural land was privatized in Romania and more than 4 million owners and around 40 million agricultural plots emerged, the storage units were privatized by sale, together with the entire chain of processing, transport and commercialization. The implementation of the Common Agricultural Policy requirements and the transformation involved by the efforts of the integration in the Common Market of the new accepted countries in the European Union generated modifications of their regional specialization and geographic concentration in certain activities.

According the opinions formulated by to Baldwin and Wyplosz (2006), two major approaches linking economic integration to change in the geographic location of economic activities. The first one is the comparative advantage which suggests nations specialise in sectors in which they have a comparative advantage. The second one is the new economic geography, according that, the integration tends to concentrate economic activity spatially. Analyzing the main theories of specialization, two opposite approaches could be identified. The theory of economic integration predicts that regional specialization generated by integration has a positive influence on the development of the regions (Helpman and Krugman, 1985; Hitiris, 1998). Baldwin and Wyplosz (2006) affirm that these gains stem from comparative advantages, increased international competition and the efficient exploitation of economies of scale. Integration in competitive markets should lead to regional specialization and product concentration within homogeneous regions. Critics to the Common Agricultural Policy suggest that that the integration policy introduces a market distortion that biases producers against product concentration within regions due to the price and income insurance provided by the Common Market.
The aim of the research is to analyze the evolution of regional specialization and geographic concentration of agriculture in Romania, as a new country of the European Union, focusing on Agriculture, forestry and fishing as a certain activity and its subactivities. The financial crisis period and its consequences over the national agriculture in terms of specialization and concentration are pointed.

The efforts made by Romania in order to fulfil the conditions imposed by the European Union for accession, but also the logistic and financial support received from it, allowed Romania's accession to the European Union on January $1^{\text {st }}, 2007$. The transformations in agriculture, prior to the process of starting the accession negotiations, in progress for approximately ten years (1990-2000), were marked by the re-establishment of the ownership right over land, which had as first consequence the de-structuring of the agricultural exploitations. The start of the negotiations influenced the evolution of the Romanian agriculture, by means of the support measures for the numerous, subsistence exploitations households that created the premises for developing commercial agricultural exploitations.

The effects on agriculture and rural development from period of Romania's pre-accession to the European Union are visible. Firstly, the compatibilization of the Romanian legislation with the Community acquis with respect to the Common Agricultural Policy, then the adaptation of the institutional system to the requirements of functioning within the communitarian European organism. The practicing of agriculture and rural development in a coherent concept, structured on seven-years periods, in a unitary system based on the strategic principles of the Common Agricultural Policy, but also taking into account the specificity of the Romanian rural space, creates the premises for assigning unprecedented investments in Romania's agricultural history financed with communitarian funds and also with private funds (Ioan, 2009). 
From the national perspective, the research actuality consists in that Romania undergoes the period of developing the Romanian Agriculture Strategy and 20142020 National Rural Development Programme. To this end, the effects of the Common Agricultural Policy and the changes it has regionally generated on the economy have to be known and evaluated, and based on these diagnoses are designed the development strategies and programmes for the next period, so as they to contribute to rural areas modernization and a more favorable integration of Romanian agriculture and rural areas in the similar structures of the European Union.

The research intends to respond if the development regions or industries, especially agriculture, in Romania have anticipated some transformation, and are already showing the first signs of a shift in their spatial-economic base. That, the hypothesis formulated by Traistaru et al. (2002) about whether industries may demonstrate a different pattern of regional localization, or alternatively, whether specific regions are able to attract new industries will be checked for the particular case of the agriculture and related activities, at the Romanian development regions. The comparison of the results will be not very conclusive, because the availability of empirical studies focused on location of industrial activity and regional transformation are individual country reports from the accession countries or

$$
\mathrm{K}_{\mathrm{i}}^{\mathrm{S}}=\sum_{\mathrm{j}=1}^{\mathrm{m}}\left|\mathrm{g}_{\mathrm{ij}}^{\mathrm{S}}-\mathrm{g}_{\mathrm{j}}\right| \text { and } \mathrm{K}_{\mathrm{j}}^{\mathrm{C}}=\sum_{\mathrm{i}=1}^{\mathrm{n}}\left|\mathrm{g}_{\mathrm{ij}}^{\mathrm{C}}-\mathrm{g}_{\mathrm{i}}\right| \text {, }
$$

Where $\left(\mathrm{K}_{\mathrm{i}}^{\mathrm{S}}\right)$ is the Krugman index for regional specialization and $\left(\mathrm{K}_{\mathrm{j}}^{\mathrm{C}}\right)$ is the

$$
g_{i}=\frac{X}{X} \text { şi } g_{j}=\frac{X}{X} \text {, where: }
$$

Additional explanations: $i$ represents the region; j represents the branch of economic activity; $X$ represents the employment; $X_{i j}$ represents the employment in the branch of economic activity $j$ in region $i ; X_{j}$ represents the employment in the branch of economic activity $j ; X_{i}$ represents the based on different system of indexes, geographical structures or economic activities (Mora and Carlos San-Juan, 2001). Additional empirical research is therefore needed for a better understanding the changes of regional specialization and geographic concentration of agriculture, during the pre-ascension process and after their ascension.

\section{Methodology}

The statistical measure used within the empirical study conducted in order to point the main transformations occurred in the geography of the Romanian agriculture during the analyzed period, in view of its aligning to the Common Agricultural Policy objectives, is the Krugman index, which is the index of specialization and concentration used in the most of regional studies (Goschin et al., 2009; Traistaru, 2002). The Krugman index used for substantiating the analysis of regional specialization and concentration of the economic activities ensures a relative measuring of these concepts. The index was used for the first time in 1993, to make a comparison between the European Union and the United States of America in terms of specialization in certain economic activities (Marelli, 2007).

The computing formulas for this index are as it follows:

Krugman index for the concentration of the economic activities and

\footnotetext{
employment in region $i ; \mathrm{g}_{\mathrm{ij}}^{\mathrm{C}}$ represents the share of region $i$ in the total national value of the branch of economic activity j; $\mathrm{g}_{\mathrm{ij}}^{\mathrm{S}}$ represents the share of the branch of economic activity $j$ in the total value of region $i$.
} 
The Krugman index, used for grounding the analisys of regional specialization and concentration of economic activities, provides a relative measuring. The indicator is used to compare a subdivision of an economic activity or a region with the whole economy of a country, ie the total area of the country. The values which indicator may have fall within the range $(0$; $2)$. The values close to 0 mean a high degree of similarity, an identical territorial or sectoral structure, whereas a value of 2 characterizes their total divergence.

The statistical indexes are computed by processing the statistical information regarding the employment of the population, on economic activities and subactivities and localization elements. The scope and the analytical character of the study are determined by the data supplied by the Romanian National Statistics Institute and the purpose of the paper. Thus, for the execution of this study the data is collected at the national level, computed for each region and the period considered covers 15 years, between 1995 and 2010.

\section{Consequences of Romania's Accession to the Common Agricultural Policy}

Starting with the $1^{\text {st }}$ of January 2007, when Romania joined the European Union as a result of complex and lengthy process that began in 1991, in which agriculture played an important part, our country had to apply the Common Agricultural Policy. In what concerns the Common market organization, in the pre-accession period, in Romania existed a liberalized market with forms of support (direct support for inputs, bonuses for wheat, export bonuses applied in the period 1999-2000), detached from production and in process of adaptation, according to the model of those applied in the European Union. The foreign trade with grains was not subjected to any restrictions. The level of the custom fees was established annually, and within the free-trade agreements concluded, for certain types of grains, were applied reductions of custom fees within tariff contingents or for unlimited quantities (in relation to the European Union and with the CEFTA countries).
Through the liberalization of the domestic trade with agricultural products, Romania confronted difficulties due to competition, both on its internal market, and on the world markets, with products strongly subsidized by its commercial partners. As a consequence of the insufficient budgetary resources, Romania's possibilities to subsidize exports were very limited. In Romania, the agricultural production benefitted in year 2001 of internal support, through the assignment of a fixed the amount for each ha of cultivated land, in come certain conditions.

For the purpose of applying the horizontal measures from the Position Document for agriculture, Romania accepted the communitarian acquis with respect to the European Agricultural Guidance and Guarantee Fund (EAGGF), and did not request a transition period. Until year 2007, the complete implementation of the institutional and legislative requirements regarding the communitarian EAGGF specific legislation was provided. The financial support granted through the first and second pillar of the CAP has entered, and is still entering, in the Romanian national economy starting with 2007 and has a different potential of impact depending on various inter-sectoral relations proper at the national level and in the lower regional levels.

A challenge that the Common Agricultural Policy had to face was that of the enlargement of the European Union, through the accession of other countries. With the two geographic expansions of 2004 and 2007, the number of agricultural workers at the level of the European Union increased. Agriculture and agricultural policy is an important issue in the European Union enlargement, because of several reasons, as it follows: the trade restrictions who remain actual in agricultural and food products, the complex instruments of the Common Agricultural Policy that rules the agricultural sector and the important impact of the accession of two largest CEECs countries, Romania and

Poland with a large share of employees in agriculture (Swinnen, 2002). The 
agricultural workers and the processing enterprises in the new member states benefitted of funds for modernization, receiving a financial allowance adapted to their needs, destined for early retirement, less developed areas, environmental protection, re-planting of forests, semi-ubsistence exploitations, and groups of producers and for the observance of regulations in matters of food merchandise, hygiene and animal welfare. Certain rules of the Common Agricultural Policy must be put into practice progressively, for the purpose of allowing an adaptation period.

\section{The Evolution of the Regional Specialization and Geographic Concentration of the Romanian Agriculture}

The analisys of regional specialization and concentration of economic activities in Romania enables determining the manner in which the changes that occurred in the Romanian economy, and mainly in the country agriculture over the last two decades, have caused changes at mesoeconomic level, and if these are included in the trends outlined by researches conducted at European Union level. In order to achieve this objective, the analysis is conducted at the eight development regions of Romania (NUTS 2). It is also passed from the analysis of agriculture compared to the other activities of the national economy for getting to the evolution analysis of sub-activities underwriting to agriculture, approached as an economic activity.

On analyzing the values calculated for Krugman index in the Romanian development regions during the period 1995-2000, summarized in Table 1 , it is found a great similarity in the specialization of Romanian development regions. Except Bucharest Ilfov Region, which has the highest economic specialization, the calculated values fall within the range $(0 ; 0.3)$. As concerns the indicator dynamics, six of the eight regions show an ascending trend of specialization in certain economic activities. By analyzing the values recorded between 2005-2010, which cover both the post-accession period and the one of economic crisis, it is noticed an increasing evolution of specialization, only in Central Region being recorded a slight decrease.

Table no. 1: Statistical Measures of Specialization Computed at NUTS2 Level Using Employment Data by Krugman Index

\begin{tabular}{|l|l|l|l|l|}
\hline Year/ Development Region & $\mathbf{1 9 9 5}$ & $\mathbf{2 0 0 0}$ & $\mathbf{2 0 0 5}$ & $\mathbf{2 0 1 0}$ \\
\hline North-West Region & 0.0957 & 0.1005 & 0.0981 & 0.1089 \\
\hline Center Region & 0.1710 & 0.1832 & 0.1562 & 0.1495 \\
\hline North-East Region & 0.1857 & 0.2011 & 0.2378 & 0.2786 \\
\hline South-East Region & 0.1473 & 0.1053 & 0.0977 & 0.1109 \\
\hline South-Muntenia Region & 0.1246 & 0.1428 & 0.1607 & 0.1891 \\
\hline Bucharest - Ilfov Region & 0.5746 & 0.6970 & 0.6160 & 0.6650 \\
\hline South-West Oltenia Region & 0.1896 & 0.1968 & 0.2053 & 0.2253 \\
\hline West Region & 0.1047 & 0.1188 & 0.1401 & 0.1557 \\
\hline
\end{tabular}

Note: The indexes are computed for the economic activities identified by the National Institute of Statistics 


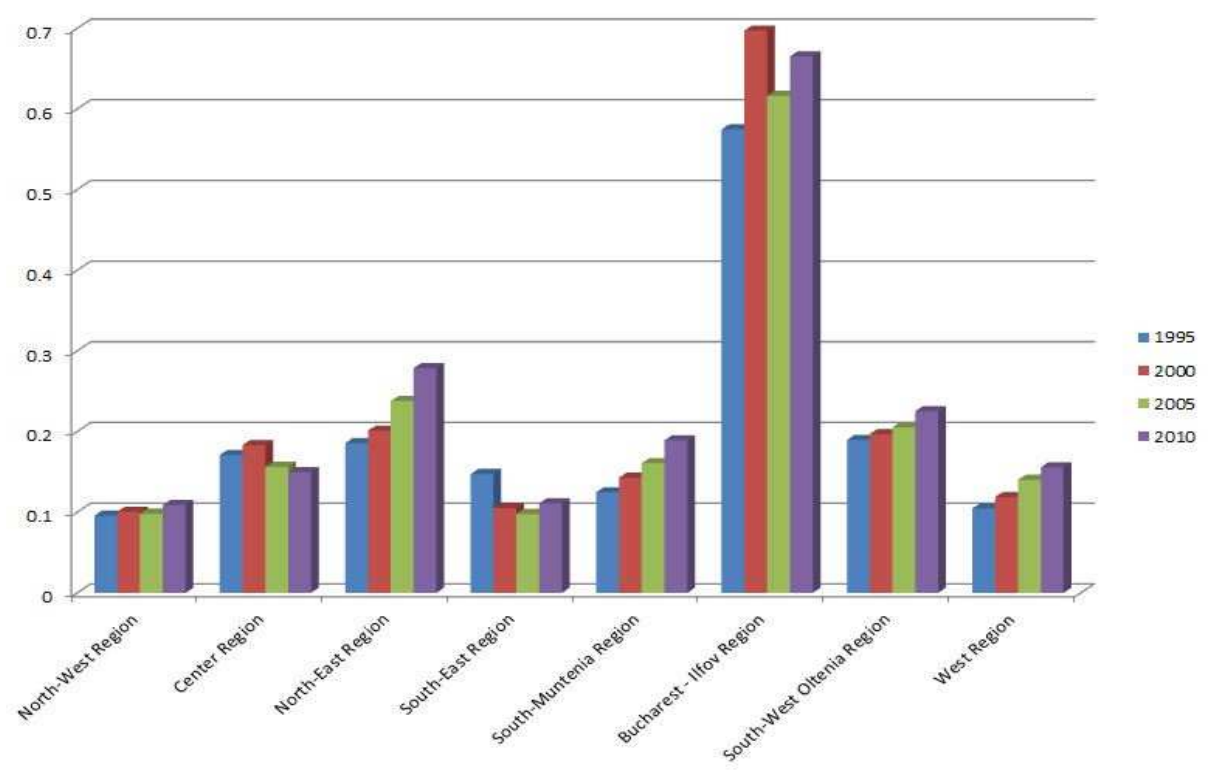

By analyzing the values calculated for Krugman index in the Romanian development regions, for Agriculture as economic activity having three distinct branches, during the period 1995-2009, synthetized in Table 2, it is found an important similarity in the specialization of Romanian development regions. Except Bucharest Ilfov Region, which records the largest specialization in agriculture, as a sub-activity of Agriculture, hunting, forestry and fishery, and Center Region, which is ranked the second, the other regions of Romania have an extremely reduced specialization, the calculated values falling within the range $(0 ; 0.02)$.
This is caused by the relatively equal distribution of natural agricultural potential at the regions level, which enables them to develop both agriculture and forestry or agriculture and fishery. Regarding the indicator dynamics, on analyzing the values recorded in the period 2005-2009 covering the post-accession time, it cannot be identified a certain trend in the specialization evolution in the three agricultural sub-activities. During the period preceding the economic crisis and also in the first time interval of its establishment, it may be noted an increasing evolution of specialization, except South West Oltenia, which recorded a slight decrease.

Table no. 2: Statistical Measures of Specialization Computed at NUTS2 Level Using Employment Data by Krugman Index

\begin{tabular}{|l|l|l|l|l|}
\hline Year & $\mathbf{1 9 9 5}$ & $\mathbf{2 0 0 0}$ & $\mathbf{2 0 0 5}$ & $\mathbf{2 0 0 9}$ \\
\hline North-West Region & 0.0080 & 0.0039 & 0.0062 & 0.0059 \\
\hline Center Region & 0.0387 & 0.0173 & 0.0205 & 0.0433 \\
\hline North-East Region & 0.0084 & 0.0046 & 0.0022 & 0.0030 \\
\hline South-East Region & 0.0194 & 0.0139 & 0.0119 & 0.0178 \\
\hline South-Muntenia Region & 0.0251 & 0.0073 & 0.0072 & 0.0162 \\
\hline Bucharest - Ilfov Region & 0.0713 & 0.0145 & 0.0071 & 0.0325 \\
\hline South-West Oltenia Region & 0.0176 & 0.0104 & 0.0134 & 0.0085 \\
\hline West Region & 0.0122 & 0.0177 & 0.0189 & 0.0248 \\
\hline
\end{tabular}

Note: The indexes are computed for Agriculture as economic activity having three distinct branches; Note: For 2010 the information has been collected at global level for agriculture, hunting, forestry and fishery 


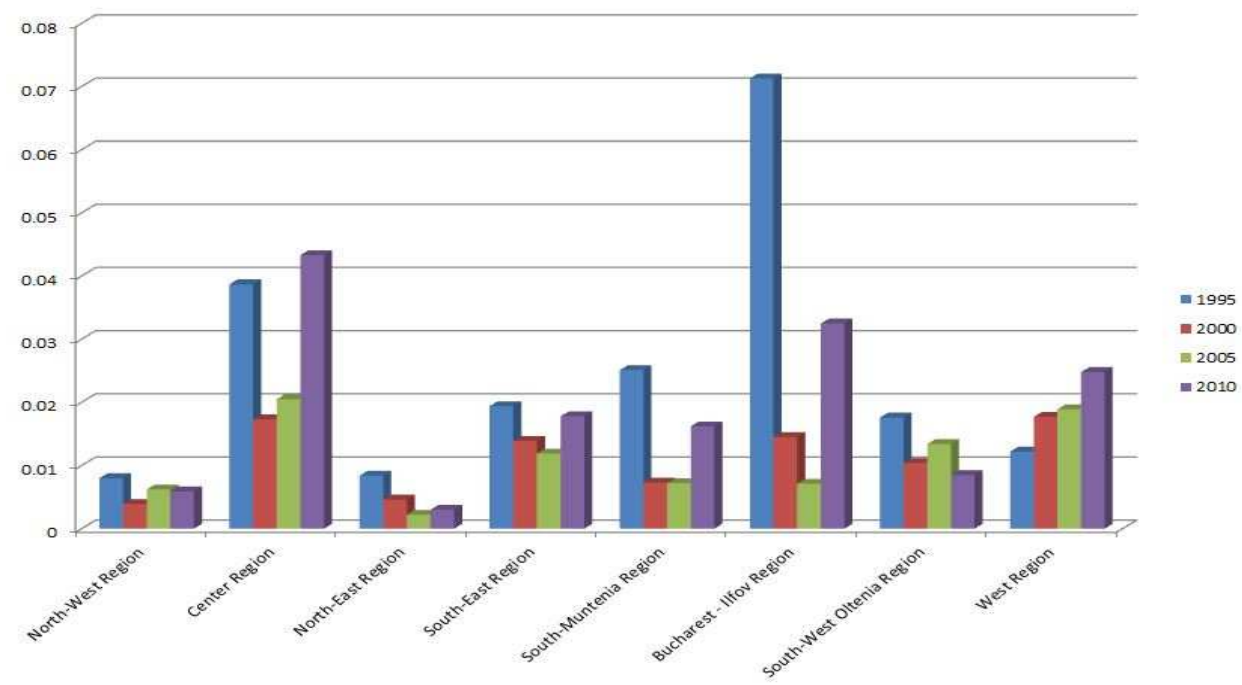

On analyzing the values calculated for Krugman index in the Romanian development regions during the period 1995-2010, summarized in Table 3, it is found a great similarity in concentration of economic activities at regional level. Except the real estate transactions, financial intermediation and other services, which represent the economic activity with the largest geographic concentration, the calculated values fall within the range $(0$; 0.3 ). Comparing these results with the economic realities and the analysis results of economic activities specialization, the
Bucharest-Ilfov Region is the region where this activity is concentrated. At the opposite are situated the social services.

Concerning the indicator dynamics, it is difficult to identify a particular trend. In the period preceding the time of joining the European Union, it may be noticed an increasing trend for most of the economic activities identified in the analysis. Agriculture is one of them, in 2010 recording one of the largest upward trends of geographical concentration.

Table no. 3: Statistical Measures of Concentration Computed at NUTS2 Level Using Employment Data by Krugman Index

\begin{tabular}{|l|l|l|l|l|}
\hline Year & $\mathbf{1 9 9 5}$ & $\mathbf{2 0 0 0}$ & $\mathbf{2 0 0 5}$ & $\mathbf{2 0 1 0}$ \\
\hline $\begin{array}{l}\text { Agriculture, forestry } \\
\text { and fishing }\end{array}$ & 0.2329 & 0.2309 & 0.2893 & 0.3351 \\
\hline Industry & 0.1213 & 0.1415 & 0.1307 & 0.1870 \\
\hline Constructions and & 0.2179 & 0.2433 & 0.2438 & 0.1143 \\
\hline Wholesale and retail (includes hotels and restaurants) & 0.1506 & 0.1919 & 0.1544 & 0.1814 \\
\hline $\begin{array}{l}\text { Transports, storage and information and real estate } \\
\text { communications }\end{array}$ & 0.3763 & 0.4277 & 0.4213 & 0.6948 \\
\hline $\begin{array}{l}\text { Financial intermediation and insurance andivities } \\
\text { activis }\end{array}$ & 0.1444 & 0.2096 & 0.1533 & 0.2707 \\
\hline $\begin{array}{l}\text { Public administration and defence; social } \\
\text { insurance of public sector }\end{array}$ & 0.1183 & 0.1134 & 0.1042 & 0.0877 \\
\hline Education & 0.0742 & 0.0948 & 0.0615 & 0.0527 \\
\hline Health and social assistance & 0.4294 & 0.3299 & 0.2877 & 0.4936 \\
\hline Other activities of the national economy & & 0.1989 & 0.2834 & 0.2162 \\
\hline
\end{tabular}

Note: The indexes are computed for the economic activities identified by the National Institute of Statistics; Note: For 2010 the information has been collected at global level for agriculture, hunting, forestry and fishery 


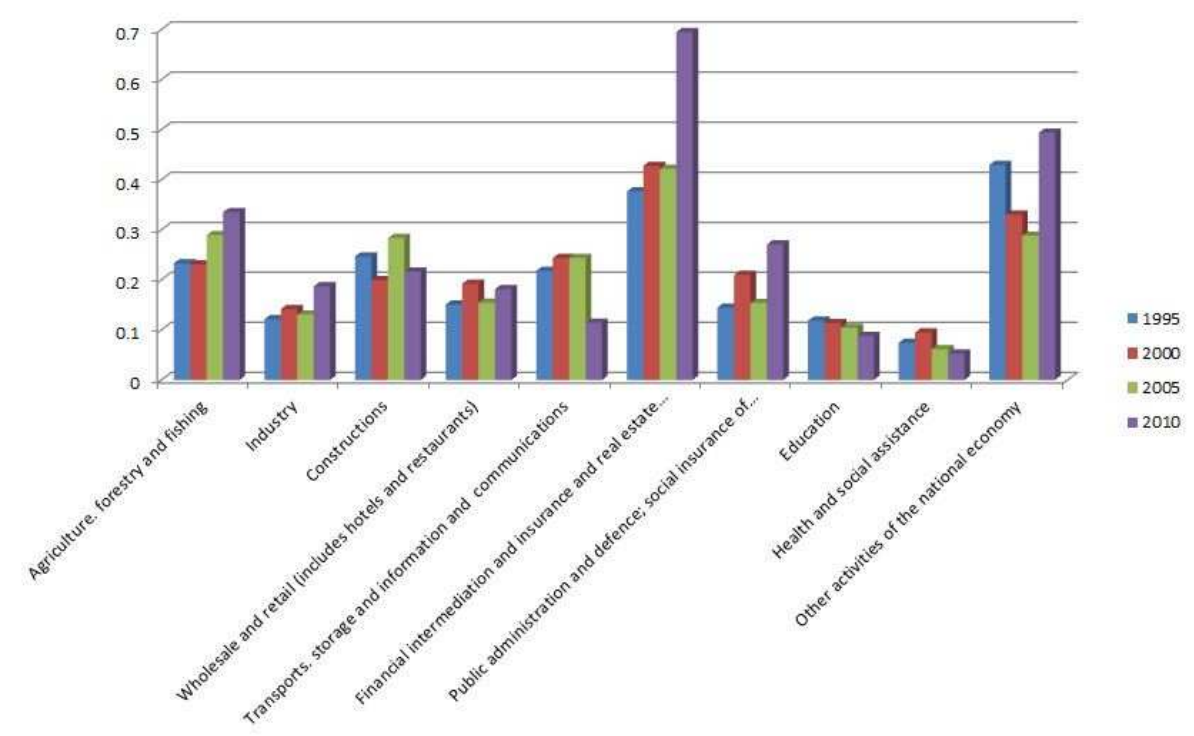

Analyzing the Krugman index values calculated for Romanian development regions during the period 1995-2009, summarized in Table 4, we find considerable differences in the concentration of three sub-activities of Agriculture as economic activity, at regional level. If agriculture shows values included in the range $(0 ; 0.8)$, Forestry, forest exploitation and hunting economy record values within the range $(0.25 ; 0.4)$, whereas Fishing and fishery values situate within the range $\left(\begin{array}{lll}0 & .9 ; 1.3\end{array}\right)$. The concentration is strictly proportional to the way in which natural resources are distributed at regional level. If agricultural land is relatively evenly distributed among the country regions, only regions having a relief composed of hills and mountains benefit from forests, while fishery resources are distributed only in few regions of Romania. As far as the indicator dynamics is concerned during 1995-2009, it is difficult to identify a particular trend. In the period preceding the accession to the European Union, an upward trend prevails, only agriculture recording a slight reduction.

Table no. 4: Statistical Measures of Concentration Computed at NUTS2 Level Using Employment Data by Krugman Index

\begin{tabular}{|l|l|l|l|l|}
\hline Year & $\mathbf{1 9 9 5}$ & $\mathbf{2 0 0 0}$ & $\mathbf{2 0 0 5}$ & $\mathbf{2 0 0 9}$ \\
\hline Agriculture & 0.0081 & 0.0035 & 0.0042 & 0.0063 \\
\hline $\begin{array}{l}\text { Forestry, forest exploitation and hunting } \\
\text { economy }\end{array}$ & 0.3787 & 0.3159 & 0.2548 & 0.3875 \\
\hline Fishing and fishery & 1.0276 & 1.3040 & 0.9538 & 1.0320 \\
\hline
\end{tabular}

Note: The indexes are computed for Agriculture as economic activity having three distinct branches; Note: For 2010 the information has been collected at global level for agriculture, hunting, forestry and fishery 


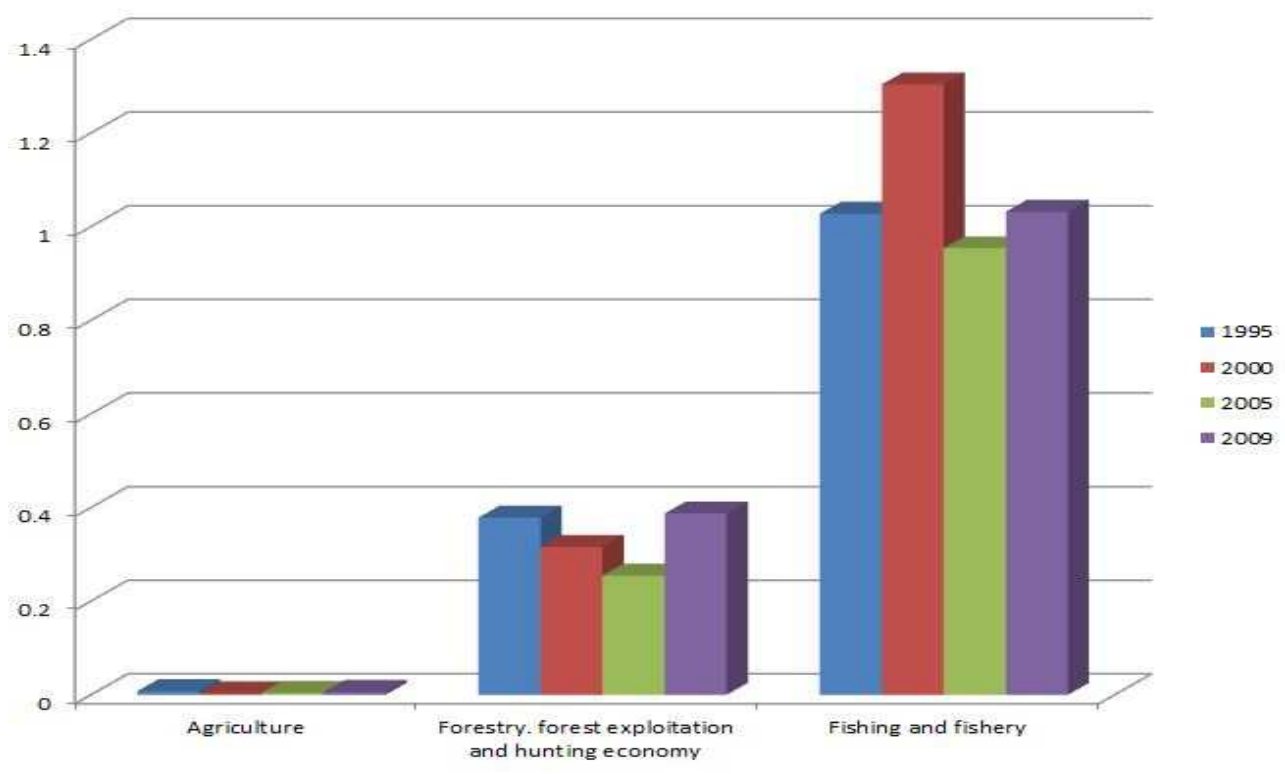

\section{Conclusions}

After submitting the accession application, in the geography of the economic activities of Romania occurred the most obvious transformations. Now emerges one of the most evident evolutions in the specialization of the economic activities at the level of all Romanian regions. The

application of the structured dialogue and of the PHARE programme, led to the cease of certain economic activities and to the development of those bringing advantages. The study conducted at the level of the Romania development regions analyzes the specialization and the concentration of agriculture as an economic branch, in comparison with the other economic activities in order to identify the correlations with the transformation made in Romanian agriculture in order to fill the criteria imposed by the European Union for the candidate countries and also, with the financial support accorded to the Romanian agriculture since the present moment. Moreover, Agriculture, Forestry, forest exploitation and hunting economy and Fishing and fishery were analyzed as sub-activities included in Agriculture.

According the Krugman index values, during the 1995-2005 period, the evolution of the agricultural specialization, beginning with 2005, at the level of the regions is not influenced by the overall trend registered at the level of the ten economic activities analyzed. In the regions with special agricultural potential, agriculture has not known a particular development, but the regions with tradition in financial and services activities agriculture had a great development, which influenced the specialisation of the national level. Concerning the period the period 2005-2010, the evolution of the specialization in the branch of Agriculture, follows the same tendencies like the economic activities analyzed within the research. Year 2007 is the starting year of the current programming period, marked by new strategic orientation in rural development. Also, it is the year of Romania's accession to the European Union, which brought forth the start of implementing the Common Agricultural Policy, including the assimilation of a new mechanism of financing agriculture and rural development from budgetary funds, regulated through the National Rural Development Programme (NRDP). In these conditions, the evolution of regional specialization is slowed down. An explanation is the fact that the major transformations occurred immediately after 1990, year 2007 finding Romania with an economy stabilized from the viewpoint of the structure and geographical distribution of the economic activities. The administrative and financial 
efforts lead to an obvious specialization and concentration of agriculture at the level of the regions known as having a high agricultural potential. In what concerns the relevance of the analysis performed, it must be mentioned that the available data cover a period until year 2009. Therefore, a part of the effects induced by the accession in the European Union manifesting after a certain time, longer than 1-2 years, could not be indicated in this study.

In conclusion, the transformations that occurred at the level of the Romanian economy in the process of pre-accession and post-accession to the European Union, the funds assigned to agriculture, lead to major changes in the weight agriculture holds in the regional economy, nor in its concentration, at the level of certain Romanian regions, but not to those with the high agricultural potential.

\section{Acknowledgement}

This work was co-financed from the European Social Fund through the Sectoral Operational Programme Human Resources Development 2007-2013, project number POSDRU/89/1.5/S/59184 „Performance and excellence in postdoctoral research in Romanian economics science domain".

\section{References}

Baldwin, R. \& Wyplosz, C. (2006). The Economics of European Integration, $M c$ Graw Hill.

Council of the European Union (1999). 'Regulation no. 1258/1999 Regarding the Financing of the Common Agricultural Policy'

Council of the European Union (2006). "Council Decision of 20 February 2006 on Community Strategic Guidelines for Rural Development (Programming Period: from 2007 to 2013)," (2006/144/EC), Official Journal of the European Union.

Giurca, D., Luca, L. \& Hurduseu, G. (2006). 'Scenarios Regarding the Impact of the Rural Development Measures on the Romanian Agricultural Structures after the
European Union,' Romanian European Institute Publishing House.

Goschin, Z., Constantin, D. L., Roman, M. \& Ileanu, B. (2009). "Regional Specialisation and Geographic Concentration of Industries in Romania," South-Eastern Europe Journal of Economics, 7(1), 61-76.

Helpman, E. \& Krugman, P. R. (1985). 'Market Structure and Foreign Trade,' The MIT Press, Cambridge, Massachusetts.

Hitiris, T. (1998). European Union Economics, Prentice Hall Europe. London.

Moga, L. M. (2011). 'Agriculture in Romania's Regional Economy Case Study for South East Region,' Proceedings of The 8th International Conference - European Economic Recovery and Regional Structural Transformations, 24-25 June 2011, ClujNapoca, Romania.

Moga, L. M. \& Antohi, V. M. (2012). "Implications of Common Agricultural Policy on the Geography of the Romanian Agriculture," Romanian Journal of Regional Science, 6(1), 71-88.

Mora Villarrubia, R. \& San-Juan, C. (2001). "Regional and Farm Specialisation in Spanish Agriculture before and after Integration in the European Union," Working Paper 01-04 Economics Series.

Swinnen, J. F. M. (2002). "Transition and Integration in Europe: Implications for Agricultural and Food Markets, Policy, and Trade Agreements," World Economy, 25 (4): 481-501.

Swinnen, J. F. M. (Editor) (2008). The Perfect Storm The Political Economy of the Fischler Reforms of the Common Agricultural Policy, Centre For European Policy Studies Brussels, 2008.

Traistaru, I., Nijkamp, P. \& Longhi, S. (2002). "Regional Specialization and Concentration of Industrial Activity in Accession Countries," Working paper, Center for European Integration Studies. 
11 Journal of Economics Studies and Research

Viorica, I. (2009). 'Financing Investment Projects. The Relationship between Feasibility Study and Business Plan,' The Annals of Dunarea de Jos University of Galati. Fascicle I. Economics and Applied Informatics

Zahiu, L., Dachin, A. \& Manole, V. (2006). 'The European Union Agriculture under the impact of Common Agricultural Policy,' CERES, Bucharest. 